\title{
Multidrug resistant tuberculous meningitis in pregnancy: a rare case report
}

\author{
U. Nagashree ${ }^{1 *}$, Charumathi ${ }^{1}$, U. Meenakshisundaram ${ }^{2}$
}

\begin{abstract}
${ }^{1}$ Department of Obstetrics and Gynecology, ${ }^{2}$ Department of Neurology, Apollo Womens Hospital, Chennai, Tamil Nadu, India
\end{abstract}

Received: 30 January 2019

Accepted: 06 March 2019

\author{
*Correspondence: \\ Dr. U. Nagashree, \\ E-mail: dr.nagashree@yahoo.com
}

Copyright: () the author(s), publisher and licensee Medip Academy. This is an open-access article distributed under the terms of the Creative Commons Attribution Non-Commercial License, which permits unrestricted non-commercial use, distribution, and reproduction in any medium, provided the original work is properly cited.

\begin{abstract}
The prevalence of tuberculosis, especially extrapulmonary tuberculosis is increasing worldwide. TB meningitis is one of severe manifestations of extra pulmonary TB. Prognosis of cases of multidrug resistance tuberculosis meningitis is worse and even more challenging in pregnant women. It's mostly associated with increased frequency of maternal disability, hospitalisation during pregnancy, foetal growth retardation, prematurity, low-birth weight and increased perinatal mortality. As information on outcome of pregnancy among women with extra pulmonary TB is limited; various medical and surgical options for timely management has been discussed. Authors bring out a case report of a primigravida at 26 weeks gestation with severe multidrug resistant TB meningitis who was successfully managed at our hospital with a healthy infant.
\end{abstract}

Keywords: Extrapulmonary tuberculosis, Hydrocephalus, Syrringomyelia, Tuberculosis meningitis

\section{INTRODUCTION}

Tuberculosis is a major public health concern worldwide, not just Asia. ${ }^{1-4}$ Although the lung remains the commonest site of infection, extrapulmonary disease is becoming more prevalent, more so in young women. TB meningitis is one of the severe manifestations of extra pulmonary tuberculosis. Hydrocephalus is one of the most common complications of TB Meningitis. But clinical features which suggest hydrocephalus in TB are nonspecific. It should be suspected in TB Meningitis patients with altered sensorium, irrespective of absence or presence of papiiloedema. It might present in patients who are alert who complain of increasing headache with or without vomiting and blurring of vision. In pregnant women with extrapulmonary tuberculosis confined to the lymph nodes has no effect on obstetrical outcomes, but tuberculosis at other extrapulmonary sites does adversely affect the outcome of pregnancy. Spinal tuberculosis, although rare in pregnancy is associated with serious morbidity. Absence of systemic symptoms and limitations to undergo radiography during pregnancy often delays diagnosis resulting in paraplegia, thereby increased risk of UTI, decubitus ulcer, autonomic hyperreflexia.

Globally MDR-TB accounts almost 5\% of all TB patients; new cases accounting to $3.5 \%$ and $20.5 \%$ of retreatment cases. Drug resistant TB may be due to genetic mutation that makes a drug ineffective against mutant bacilli. Multidrug resistant phenomenon could also be due to primary infection with resistant strains or who develop multidrug resistance during incomplete medical treatment. MDR-Tb meningitis is increasing worldwide and is difficult to diagnose and treat. Outcome of TB meningitis with hydrocephalus is based on the disease response to ATT. It could be poor in MDR-TB or extensively drug resistant -XDR-TB. 


\section{CASE REPORT}

A 25 -year-old primi at 26 weeks gestation was admitted on $3^{\text {rd }}$ July 2017 with complaints of severe headache for 15 days; mostly bifrontal, associated with blurring of vision on right eye for 3 days and gum bleed. Her GCS was $15 / 15$. MRI/MRV was done outside which suggested cerebral venous thrombosis.

So, authors started Injection Enoxaparin $0.4 \mathrm{ml} \mathrm{sc}$ tentatively. MRI/MRV done at our hospital on $6^{\text {th }}$ July 2017 revealed edema in postero inferomedial aspect of left thalamus extending into left tectal plate-mostly midbrain superior colliculus. CSF analysis showed glucose $-27 \mathrm{mg}$, protein $94 \mathrm{mg}$. Cell cytology showed lymphocytes-96\%. CSF for meningo encephalitis panel was negative, X-pert MTB was negative. Considering her CSF picture, ATT was started empirically. Opinion from pain management consultant was taken and managed. As the headache didn't subside, injection Methyl prednisolone $500 \mathrm{mg}$ Iv started. Her headache was relieved. Vasculitis package showed ANA++++ homogenous 1:40 substrate Hep -2 cells.Her repeat MRI/MRV showed features of meningitis. Repeat CSF analysis showed glucose $17 \mathrm{mg}$, protein $80 \mathrm{mg}$. Cell cytology showed lymphocytes $-99 \%$. Opinion of gynecologist taken and foetal well being assessed regularly. Family members were explained about pros and cons of medications during hospital stay. Liver enzymes were elevated, but decision to continue ATT was taken after discussing with the family members. She was discharged on $17^{\text {th }}$ July 2017 with advice to continue Injection clexane and tablet prednisolone $20 \mathrm{mg}$. She was readmitted after a week on $25^{\text {th }}$ July 2017 with c/o irrelevant talk and urinary incontinence for 2 days. MRI showed diffuse cerebral edema (Figure1), effacement of sulcal spaces and basal cisterns; moderately communicating hydrocephalus with periventricular seepage, acute infarction in basal ganglia.

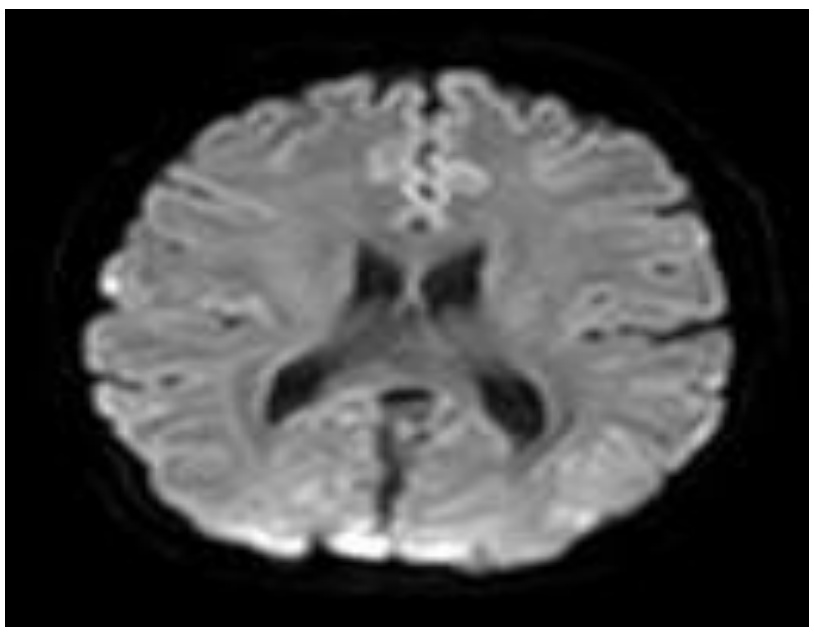

Figure 1: Dilated ventricles with cerebral edema.

In view of the worsening condition of the patient, decision to proceed with elective LSCS and right frontal external ventricular drain insertion was taken after discussing in an interdepartmental meeting. She underwent planned LSCS on $27^{\text {th }}$ July 2017. A preterm boy baby of $29 \pm 5$ weeks gestation weighing $1.3 \mathrm{~kg}$ delivered with Apgar of 8/10, 9/10 and was shifted to NICU.

Baby was electively intubated, and surfactant given, baby extubated the next day. Initial sepsis screen, Retinopathy of prematurity and Inborn Error Metabolism was negative. Neurosonogram done on alternate days was normal. ID consultation was obtained, no neonatal TB diagnosed. Baby was taking feeds from day 3 satisfactorily. Mother was shifted to MDCCU. She developed respiratory distress on $29^{\text {th }}$ July 2017, so she was intubated. CT brain on $1^{\text {st }}$ August 2017 shows drain tip in right ventricle. Gross dilatation of left ventricle was more than right, third and fourth ventricle; significant periventricular seepage and cerebral edema was seen. GCS on $2^{\text {nd }}$ August 2017 is E3VTM4.

Considering drop in GCS; repeat CT was done which shows mild reduction in size of ventricles, significant cerebral edema; leptomeningeal enhancement. Decision to proceed with immediate Ventriculoperitoneal shunt taken. She was reintubated on $4^{\text {th }}$ August 2017 after the procedure. Percutaneous tracheostomy done to prevent ventilator associated pneumonia.

She became drowsy on $8^{\text {th }}$ August 2017 with GCS of E3VTM6. CT revealed same findings of hydrocephalus; tip of external ventricular drain in right lateral ventricle. EEG showed diffuse bilateral cerebral dysfunction, dosage of anti-epileptic drugs adjusted. Her condition gradually improved over a week. She was responding to oral commands, moving both upper limbs. So, she was shifted to HDU on $15^{\text {th }}$ August 2017 and was weaned to intermittent BiPAP. She had motor neuropathy of all four limbs. She was started on second line off ATT drugs in view of worsening hepatitis, resistance to 1st line ATT drugs. She was started on Dexamethasone and Enoxaparin.

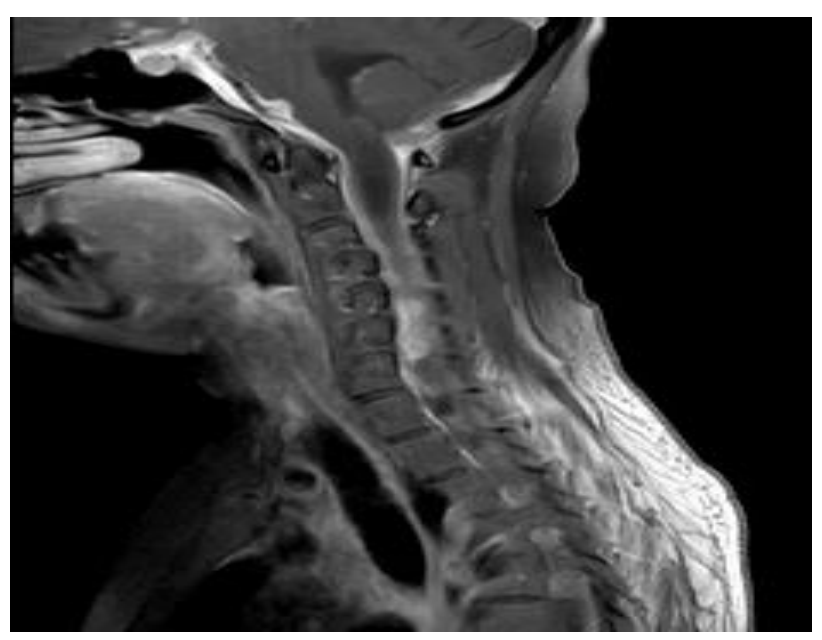

Figure 2: Holocord syringomyelia. 
She was planned for discharge in September as she was maintaining well on 2 litres of $\mathrm{O}_{2}$, on $1900 \mathrm{kcal}$ diet; $90 \mathrm{~g}$ protein, parenteral feed with trial oral feed. She was followed up every 2 weeks as OP. She is tolerating soft solids well. Post gadolinium whole spine showed mild diffuse circumferential meningeal thickening with patchy and leptomeningeal enhancement. Severe axonal motor polyneuropathy noted in both lower limbs. Second line of ATT was stopped in view of amikacin induced ototoxicity in april 2018.Weakness of lower limbs is more pronounced than upper limbs. Diffuse craniospinal meningitis associated with syringomyelia holocord seen (Figure 2), so second line of ATT drugs with steroids restarted with strict monitoring.

\section{DISCUSSION}

Tuberculosis is a major public health concern all over the world. In India, mortality due to TBM is $1.5 / 1,00,000 .^{5}$ Extrapulmonary TB is present in 10 to $27 \%$ of all pts with TB. ${ }^{6-9}$ Diagnosis of this is often delayed due to its protean manifestation. ${ }^{6-9}$ Extrapulmonary $\mathrm{TB}$ is rare among pregnant women. ${ }^{10-13} \mathrm{~TB}$ meningitis in pregnant women is associated with neurologic morbidity and increased risk of death to both the women and their infants. $^{11}$

Biopsy and surgical intervention may not be possible in pregnancy because of the risk of preterm labour, poor accessibility of lesions and anaesthetic risk to foetus. ${ }^{12}$ TB lymphadenitis-most common form of extrapulmonary TB has no adverse effect of maternal and foetal outcome. ${ }^{6,8,14}$ Hydrocephalus is one of the most common complications of TBM. It presents in patients with the disease after 4-6 weeks. ${ }^{15}$

Hydrocephalus could be communicating (most common) or the obstructive type. In early stages, thick gelatinous exudates block subarachnoid spaces in the base of brain leading to communicating hydrocephalus. ${ }^{16}$ Secondly inflammation could lead to excess CSF production. It leads to hydrocephalus with raised intracranial pressure. Treatment with ATT poses special problems during pregnancy due to possible teratogenic effects.

\section{Medical management}

It might be offered as first line of therapy to patients with communicating hydrocephalus. ${ }^{17}$ It comprises steroids dehydrating agent's mannitol; diuretics such as frusemide and acetazolamide to reduce CSF production.

Tapering doses of dexamethasone 12-16 mg for 4-6weeks can be given. Mannitol is not to be given for more than 72 hours.

Acetazolamide $100 \mathrm{mg} / \mathrm{kg}$ and frusemide $1 \mathrm{mg} / \mathrm{kg}$ can be given for longer periods up to a month. Along with them ATT helps in reducing inflammatory response leading to opening of CSF pathways.
Drug resistant tuberculosis of CNS requires longer therapy preferably 1 year. Initiation phase for 2 months with four drugs (Isoniazid + Rifampin + Pyrazinamide + Ethambutol) HRZE.

Continuation phase for 10 months-two drugs HR, three drugs in case of isoniazid resistant. Proper pre-treatment evaluation is needed before starting MDR TB treatment. World health organization (WHO) also recommends XPERT TB test

For MDR TB; anti-TB drugs are grouped according to efficacy, experience of use and drug class.

\section{Surgical management}

Surgery is indicated in brain tuberculosis for hydrocephalus and tuberculomas, and those with nonresponsive medical therapy. Most often ventriculoperitoneal (VP) shunt and endoscopic third ventriculostomy (ETV) are advisable. ETV is more successful in patients with hydrocephalus. Complications of shunt are infection and skin erosion.

\section{CONCLUSION}

Effects of extrapulmonary TB on pregnancy depends on sites involved; severity and duration of disease; occurrence of pregnancy associated complication. Definitive or gold standard tests are not possible in most cases of CNS-TB. The decision to stop first line ATT and start second line ATT should be prompt and precise. So vigilant clinical observation, lab tests and neuroimaging are major decisive tools. Medical and timely surgical management depending on the situation plays an important role.

\section{Funding: No funding sources \\ Conflict of interest: None declared \\ Ethical approval: Not required}

\section{REFERENCES}

1. Kochi A. The global tuberculosis situation and the new control strategy of the world health organization. Tubercle. 1991;72:1-6.

2. Snider DE Jr, Roper WL, The new tuberculosis. N Eng J Med. 1992;326:73-5.

3. Davies PD. Tuberculosis and HIV: blind man's buff. Thorax. 1993;48(3):193.

4. Darbyshire JH. Tuberculosis: old reasons for a new increase? BMJ. 1995;310:954.

5. Chakraborty AK. Estimating mortality from tuberculous meningitis in a community: use of available epidemiological parameters in the Indian context. Prevalence. 2000;10:1000.

6. Dwyer DE, Macleod CO, Collignon PJ, Sorrell TC. Extrapulmonary tuberculosis a continuing problem in Australia. Aus New Zeal J Med. 1987;17(5):507-11. 
7. Hayward AC, Watson JM. Tuberculosis in England and Wales 1982-1993: notifications exceeded predictions. Communicable disease report. CDR Review. 1995;5(3):R29-33.

8. Farer LS, Lowell AM, Meador MP. Extrapulmonary tuberculosis in the United States. Am J Epidemiol. 1979;109(2):205-17.

9. Naqvi SQ, Memon JM, Akhund AA, Taqi T. Tuberculosis of the breast: a cytomorphological study of nine cases. PJS. 2007;23(4):237-41.

10. Govender MJ. Tuberculous paraplegia during pregnancy-a report of 4 cases. South African Med J. 1989 1;75(4):190-2.

11. Kingdom JC, Kennedy DH. Tuberculous meningitis in pregnancy. BJOG: An Int J Obstet Gynaecol. 1989;96(2):233-5.

12. Casper GR, Heath P, Garland SM. A pain in the neck in pregnancy: cervical spinal tuberculosis. Australian and New Zeal J Obstet Gynaecol. 1995;35(4):398400 .

13. Schaefer G, Douglas RG, Dreishpoon IH. Extrapulmonary tuberculosis and pregnancy. Am J Obstet Gynecol. 1954;67(3):605-15.
14. Lau SK, Kwan S, Lee J, Wei WI. Source of tubercle bacilli in cervical lymph nodes: a prospective study. J Laryngol Otol. 1991;105(7):558-61.

15. Tandon PN. Tuberculous meningitis (cranial and spinal ). In Vinken PJ, Bruyn GW, eds. Handbook of Clinical Neurology. Infections of the nervous system.Amsterdam:North-Holland.1978;33:195-262.

16. Dastur DK, Manghani DK, Udani PM. Pathology and athogenetic mechanisms in neuro tuberculosis. Radiol Clin North Am. 1995;33:733-52.

17. Lampreeht D, Schoeman J, Donald P, Hartzenberg H. Ventrculoperitoneal shunting in childhood tuberculous meningitis. $\mathrm{Br} J$ Neurosurg. 2001;15:119-25.

Cite this article as: Nagashree U, Charumathi, Meenakshisundaram U. Multidrug resistant tuberculous meningitis in pregnancy: a rare case report. Int J Reprod Contracept Obstet Gynecol 2019;8:1692-5. 